\title{
Last interglacial vegetation in northern Asia: Model simulations and comparison with pollen-based reconstructions
}

\author{
Martin Bergemann ${ }^{\mathrm{a}, \mathrm{b}}$, Stefanie Müller ${ }^{\mathrm{c}, *}$ \\ a Institute of Meteorology, Freie Universität Berlin, Carl-Heinrich-Becker-Weg 6-10, 12165 Berlin, Germany \\ ${ }^{\mathrm{b}}$ School of Mathematical Sciences, Faculty of Sciences, Monash University, Clayton-Campus, VIC 3800, Australia \\ ${ }^{\mathrm{c}}$ Institute of Geological Sciences, Palaeontology, Freie Universität Berlin, Malteserstrasse 74-100, Building D, 12249 Berlin, Germany
}

\section{A R T I C L E I N F O}

Article history:

Available online $\mathrm{xxx}$

\begin{abstract}
A B S T R A C T
This study is concerned with vegetation modelling in northern Asia and its comparison with pollenbased vegetation and climate reconstructions. With the help of BIOME1, a global biogeographic equilibrium vegetation model, vegetation dynamics during the last interglacial (LI) period in the northern Asian region can be simulated. In the study, an alternative algorithm to calculate a moisture index $(\alpha)$ is implemented, and the vegetation is modelled for the optimum phase (125 ka BP) and the end of the LI period (115 ka BP). The simulations show an approximately $28 \%$ increase in the area occupied by forest biomes for the $125 \mathrm{ka}$ BP time-slice and an approximately $14 \%$ decrease in forest-dominated areas around $115 \mathrm{ka}$ BP in comparison to today. Compared to the present day, the tree-line for the $125 \mathrm{ka}$ BP time-slice was located on average $4.05 \pm 2.03^{\circ}$ further north. Comparison of the modelled results with available pollen-based reconstructions shows that the simulated and reconstructed results for the optimum of the LI period are consistent. With both algorithms calculating the moisture index $\alpha$, i.e. $\alpha_{1}$ and $\alpha_{2}$, the tree line shifts back $\left(\sim 10 \pm 4.4^{\circ}\right)$ between the optimum and the end of the LI period. The area occupied by forest in both simulations had declined by an average of $\sim 42 \%$. Furthermore, the data-model comparison shows that the modelling results obtained with the newly implemented moisture index are in slightly better agreement with the climate reconstructions.
\end{abstract}

() 2013 Elsevier Ltd and INQUA. All rights reserved.

\section{Introduction}

The terrestrial biosphere plays a pivotal role in the Earth's climate through biophysical interactions with the atmosphere and hydrosphere (Foley et al., 1994; Texier et al., 1997). Therefore, understanding the feedback mechanisms between climate and biosphere is a vital key for the description of the past climate and its future development. As with climate, the vegetation can be simulated with numerical models, resulting in a variety of approaches. Because plant growth and vegetation composition are strongly dependent on climate (e.g. Prentice et al., 1992), modelling vegetation changes, especially when compared with vegetation records, has been shown to have a high potential for objective simulation of the natural vegetation and climate history (Kleinen et al., 2011). Furthermore, an excellent overview of the development of dynamic global vegetation models (DGVMs) by several research groups focusing on natural environmental and anthropogenic processes is

\footnotetext{
* Corresponding author.

E-mail address: stefm@zedat.fu-berlin.de (S. Müller).
}

given in Prentice et al. (2007), examining 'plant geography', 'plant physiology and biogeochemistry', 'vegetation dynamics', and 'biophysics' as well as 'human intervention: agriculture, urbanisation and forest management'.

Several vegetation models such as BIOME4 (Kaplan et al., 2003), LPJ (Sitch et al., 2003) and ORCHIDEE (Krinner et al., 2005) use various equations to simulate physiological processes such as photosynthesis, carbon allocation and respiration to simulate plant growth. However, as there is no analytical basic equation to describe plant growth as a whole, the simulation of vegetation involves several problems. The present case study uses the BIOME1 model (Prentice et al., 1992), a biogeographic equilibrium-model. This model establishes a connection between five bioclimatic indices and vegetation dynamics. These indices are the mean monthly temperature of the warmest and coldest months $\left(T_{w}, T_{C}\right)$, the annual sum of growing degree days above $5{ }^{\circ} \mathrm{C}$ and $0{ }^{\circ} \mathrm{C}\left(G D D_{5}\right.$, $\left.G D D_{0}\right)$ and a moisture index $(\alpha)$. The moisture index $\alpha$ was introduced in order to describe a plant's moisture budget (Priestley and Taylor, 1972; Wilson et al., 2001; Ajami et al., 2011). The BIOME1 model should be forced with outputs from a climate model at equilibrium. Based on such an equilibrium climate, the spatial 
distribution of ecosystem complexes can be compared with vegetation maps or proxy data. The BIOME1 model was successfully used to simulate palaeovegetation despite its intermediate level of complexity (Prentice et al., 1996; Roeckner et al., 1996; Sánchez Goñi et al., 2005).

For those palaeoclimatic reconstructions and simulations, the last interglacial (LI), the most recent analogue for the current interglacial period with similar climatic conditions (Brewer et al., 2008), is of special interest because the climate and vegetation dynamics during the LI period may provide important insights to enhance our understanding of the Earth's system under the recent progress of global warming (IPCC, 2007). For this period, research has focused on the sea-level and vegetation dynamics as well as the influence of solar radiation (Cuffey and Marshall, 2000; Kubatzki et al., 2000; Crucifix and Loutre, 2002; Cubasch et al., 2006; Schurgers et al., 2006). In general the climatic conditions during the LI had higher temperatures than today (Kukla et al., 2002). The beginning of the LI has been set at ca. $130 \mathrm{ka}$, and its end at ca. 115 ka (Jouzel et al., 2007). Sánchez Goñi et al. (2005) reconstructed the LI vegetation and climate gradient in Western Europe with the help of pollen data and compared the results with circulation and vegetation model simulations. Kaspar et al. (2005) simulated the climate with a coupled atmosphere ocean model (ECHO-G) for the optimum of the LI (125 ka BP) and used the simulation results for a data-model comparison in the European region. The investigation shows that the model used here (ECHO-G) is able to simulate the climate during the LI optimum satisfactorily. The five climate indices that are needed to drive the BIOME1 model have been calculated by Kageyama et al. (2001) with climatic outputs from different climate models from the PMIP project simulations for Europe and western Siberia. There, MoBidiC (Gallée et al., 1991) was used to model the atmosphere whereas BIOME1 was used to compute the moisture index. The simulations were done for the last glacial maximum, ca. $21 \mathrm{ka} \mathrm{BP}$, and showed a broad agreement with pollen-based reconstructions, except for Western Europe where the moisture index $\alpha$ is overestimated by the model simulations.

In this study, we compare results of model simulations to climate and vegetation reconstructions based on proxy records which may help to validate these results to better understand the different climate factors influencing past environments within the region of north Asia. Until now, there have been only a few investigations (Harrison et al., 1995; Melles et al., 2012) on this subject for the northern Asian region during the LI period. This raises the question whether the mentioned discrepancy between model simulations and proxy reconstructions is only valid for glacial conditions or also for interglacial phases in this region. To answer this question, we first examine the vegetation dynamics during two pronounced phases of the LI - at the optimum (125 ka BP) and end (115 ka BP) of the LI (Jouzel et al., 2007). The BIOME1 model has been used to simulate the vegetation, whereas the vegetation is calculated using climate simulations according to Kaspar et al. (2005). Furthermore, we implement an alternative method for calculating $\alpha$ and investigate whether this provides an improvement compared to the original method described by Prentice et al. (1991). Furthermore, the obtained simulation results are compared with published pollen-based vegetation and climate reconstructions from sites in northern Asia.

\section{Experimental design}

\subsection{Calculation of moisture index $\alpha$}

In this study, two approaches of calculating the moisture index $\alpha$ (further called $\alpha_{1}$ and $\alpha_{2}$, respectively) are presented. Therefore, two different sets of physical climate variables are used to drive the
BIOME1 model. The first approach calculates $\alpha_{1}$ (moisture index as in Prentice et al., 1992) using total cloud cover, surface temperature, total precipitation and available water capacity. Alternatively, in the current study moisture index $\alpha_{2}$ is calculated differently from Prentice et al. (1992) using surface temperature, and latent and sensible heat flux.

The vegetation cover is described by a combination of so called plant functional types (PFTs) whereas the PFTs are defined by several environmental and ecological properties (Woodward and Cramer, 1996); these are basic physiognomy (trees and non-trees) and leaf characteristics (evergreen and deciduous, broad-leafed and needle-leafed). In BIOME1 thirteen PFTs and an additional dummy type are defined and allocated to climatic conditions according to the climate variables of $T_{c}, T_{w}, G D D_{5}, G D D_{0}$, and $\alpha$ (Prentice et al., 1992). The latter variable can be considered as an integrated measure of the annual amount of growth-limiting drought stress on plants (Prentice et al., 1992). The index is also called the Priestley-Taylor coefficient because it is the linear constant of proportionality in the Priestley-Taylor equation $E=\alpha^{*} E_{q}$ (Priestley and Taylor, 1972). $E$ is the evapotranspiration and $E_{q}$ the equilibrium evapotranspiration, which is an expression for the radiation part within the Penman-Monteith equation for evapotranspiration (Monteith, 1965). All variables besides $\alpha$ can be derived directly from the climate model output. In the vegetation simulation, the plant competition for sunlight and soil moisture is expressed with a dominance class $(D)$. After applying the environmental limits to determine which plant types can occur, the dominance class values of these types are examined and only those in the highest class (lowest $D$ ) are retained in the code indicating the biome type. The climate indices are calculated on a yearly basis and an average of the whole simulation period is applied to assign the dominance type of the PFTs. In the second step, the PFTs are assigned to their corresponding biomes (Prentice et al., 1992).

The procedure applied in this study can basically be separated into two steps. First, the new implemented algorithm for calculating $\alpha$ is tested with NCEP/NCAR reanalysis climate data (NOAA and NCAR, 1949-2011; Kalnay et al., 1996) in order to compare the results with a satellite based vegetation map from Olson et al. (1983). Secondly, the vegetation during the optimum and end of the LI is simulated with the help of ECHO-G simulations (Kaspar et al., 2007) and tested with the Cohens- $\kappa$-statistics (Cohen, 1968; Monserud and Leemans, 1992). All reanalysis data is provided by the physical-scientific department of NOAA-ESRL in Boulder, Colorado via the website http://www.esrl.noaa.gov/psd/. The gridresolution of the modern climate data is T62 (ca. $\left.1.875^{\circ}\right)$. The BIOME1 model is driven by an equilibrium climate based on the years from 1978 to 2008 . As this work focuses on the simulation of palaeovegetation derived from a climate model, the validation is based on reanalysis climate data and not on observational data.

\subsection{Last interglacial (LI) vegetation simulation}

The equilibrium climate for the palaeovegetation simulation is based on ECHO-G climate specifications (Legutke and MaierReimer, 1999; Legutke and Voss, 1999). The ECHO-G is a coupled atmosphere ocean climate model, for which the ECHAM4 is the basis for the atmosphere simulations (Roeckner et al., 1996). The spatial horizontal resolution of the atmosphere model is T31 $\left(\approx 3.75^{\circ}\right.$ ). The model has 19 vertical hybrid sigma-pressure levels. The basis for the ocean component of ECHO-G is HOPE-G (Wolff et al., 1997). It provides a dynamic-thermodynamic sea-ice model (Hibler, 1979) with a spatial resolution of T42 $\left(\approx 2.8^{\circ}\right)$ and 20 vertical, irregularly ordered layers. ECHO-G control run simulations by Min et al. (2005a) show that the present climatology and interannual variability of surface temperature, precipitation and sea 
surface temperature is simulated reasonably well. The simulation of El Niño Southern Oscillation (ENSO) and the North Atlantic Oscillation (NAO) also shows reliable results (Min et al., 2005b).

In this investigation, the applied climate simulations are based upon two time-slice simulations for the optimum (125 ka BP) and the end (115 ka BP) of the LI that are accomplished by Kaspar et al. (2007). The simulations are performed as equilibrium experiments with constant boundary conditions (Table 1). The orbital parameters are calculated according to Berger (1978). The greenhouse gas concentrations are related to the values from the Vostok ice core (Petit et al., 1999; Sowers, 2001). The remaining boundary conditions, including land-sea distribution, are set to present-day conditions. For both time-slices, a transient phase lasting 600 years is assumed. The vegetation model is driven over a 300 year period on average. This period marks the temporal boundary where the icemodel tends to instability. This leads to an overestimation of the thickness of the North American ice shield.

\section{Table 1}

Compilation of orbital parameters (Berger, 1978) and main greenhouse gas concentrations $\left(\mathrm{CO}_{2}, \mathrm{CH}_{4}\right.$ and $\left.\mathrm{N}_{2} \mathrm{O}\right)$ according to Petit et al. (1999) and Sowers (2001) for the optimum (125 ka BP) and end (115 ka BP) of the LI as described in Kaspar et al. (2007) and used in this study. For comparison the pre-industrial values are listed.

\begin{tabular}{llll}
\hline & 125 ka BP & 115 ka BP & Pre-industrial \\
\hline Numerical Eccentricity & 0.4000 & 0.04141 & 0.0167 \\
Obliquity [ $^{\circ}$ [ & 23.79 & 22.41 & 23.44 \\
Perihelion [ $^{\circ}$ ] & 127.3 & 290.9 & 282.7 \\
$\mathrm{CO}_{2}[\mathrm{ppmv}]$ & 270 & 265 & 280 \\
$\mathrm{CH}_{4}[\mathrm{ppbv}]$ & 630 & 520 & 700 \\
$\mathrm{~N}_{2} \mathrm{O}$ [ppbv] & 260 & 270 & 265 \\
\hline
\end{tabular}

\subsection{Regional settings for the modern vegetation}

Northern Asia, is known to play a major role in the global climate system influencing the oceanic and atmospheric circulation through strong interactions involving ocean, atmosphere, cryosphere, and terrestrial processes (e.g. Melles et al., 2012). Therefore, we investigated in this study the region extending from the west Siberian lowland $\left(71.5^{\circ} \mathrm{E}\right)$ via the Siberian Plateau to the Bering Strait in the east $\left(172.5^{\circ} \mathrm{W}\right)$. In the north, the region is bordered by the Arctic Ocean $\left(79^{\circ} \mathrm{N}\right)$. Northern China forms the southern boundary of the study region. Despite the considered modern vegetation is composed of different plant associations and communities, tundra, taiga and cold deciduous forest are the most dominant biomes in this region.

\section{Methods}

The original calculation of biomes in BIOME1 was introduced by Prentice et al. (1992). Since that time, no other adaptations for calculation of moisture index $\alpha$ were made. In the following text the moisture index calculated with the algorithm by Prentice et al. (1992) is referred to as $\alpha_{1}$ whereas the alternatively implemented algorithm is called $\alpha_{2}$.

\subsection{Calculation of $\alpha_{1}$}

In the Equation (1) the soil heat flux is neglected and the equilibrium evapotranspiration is expressed as:

$$
E_{q}=\int_{-\delta / 2}^{\delta / 2} \mathrm{dt} \frac{\Delta * R_{n}}{\lambda(\Delta+\gamma)} * \cos t
$$

with:

$R_{n}\left[\mathrm{~W} \mathrm{~m} \mathrm{~m}^{-2}\right]$ - net radiation at ground level

$\Delta\left[\mathrm{Pa} \mathrm{K}^{-1}\right]$ - slope of the water vapour pressure curve

$\gamma-$ psychrometer constant $\left(\sim 65 \mathrm{~Pa} \mathrm{~K}^{-1}\right.$ at $\left.293 \mathrm{~K}\right)$

$\lambda$ - latent heat of water vaporisation $\left(\sim 2.45 \mathrm{MJ} \mathrm{kg}^{-1}\right.$ at $\left.293 \mathrm{~K}\right)$

Hereby, the sun is supposed to follow a sinusoidal course within the period from sunrise $-\delta / 2$ to sundown $\delta / 2$. A more detailed description for calculating the single variables of Equation (1) is given in Prentice et al. (1991).

The actual evapotranspiration in the Priestley-Taylor equation is derived from the scheme of Federer (1982). In this model the actual evapotranspiration is the minimum of a daily demand $(D)$ and supply $(S)$ function. The supply function is a soil water reservoir from which moisture evaporates with a constant rate $c_{w}=1 \mathrm{~mm} / \mathrm{h}$. In general the solar net radiation $R_{n}$ causes the evapotranspiration $E$. $R_{n}$ is proportional to the equilibrium evapotranspiration $E_{q}$, which expresses the demand function $D$ (Fig. 1). Finally the soil moisture index $\alpha_{1}$ is calculated with the following equation:

$\alpha_{1}=\frac{\sum_{i=1}^{i=N} E}{\sum_{i=1}^{i=N} E_{q}}$

with $N$ indicating the number of days per year.

\subsection{Calculation of $\alpha_{2}$}

The method of determining the alternatively implemented moisture index begins with the parameterisation of the evapotranspiration (Lettau, 1969). The balance equation for the instantaneous net radiation flux at ground level in thermodynamic equilibrium is the first basis for the derivation of $\alpha_{2}$ :

$R_{n}=(1-\psi)^{*} R_{s} \downarrow+\varepsilon R_{1} \downarrow-\varepsilon \sigma T_{s}^{4}=G+H+\lambda E$

with:

- $\lambda E\left[\mathrm{~W} \mathrm{~m}_{2}^{-1}\right]$ - latent, $H\left[\mathrm{~W} \mathrm{~m}_{2}^{-1}\right]$ - sensible heat flux into the atmosphere

- $G\left[\mathrm{~W} \mathrm{~m}_{2}^{-1}\right]$ - heat flux into the ground

- $R_{s} \downarrow\left[\mathrm{W} \mathrm{m} \mathrm{m}^{-1}\right]$ - downward short wave radiation

- $R_{\mathrm{l}} \downarrow\left[\mathrm{W} \mathrm{m} \mathrm{m}^{-1}\right]$ - downward long wave radiation

- $\varepsilon$ [] - emissivity of the atmosphere

- $T_{s}[K]$ - surface temperature

- $\psi[]$ - surface albedo

- $\sigma\left[5,67^{*} 10^{8} \mathrm{~W}\left(\mathrm{~m}^{2} \mathrm{~K}^{4}\right)^{-1}\right]$ - Stefan-Boltzmann constant

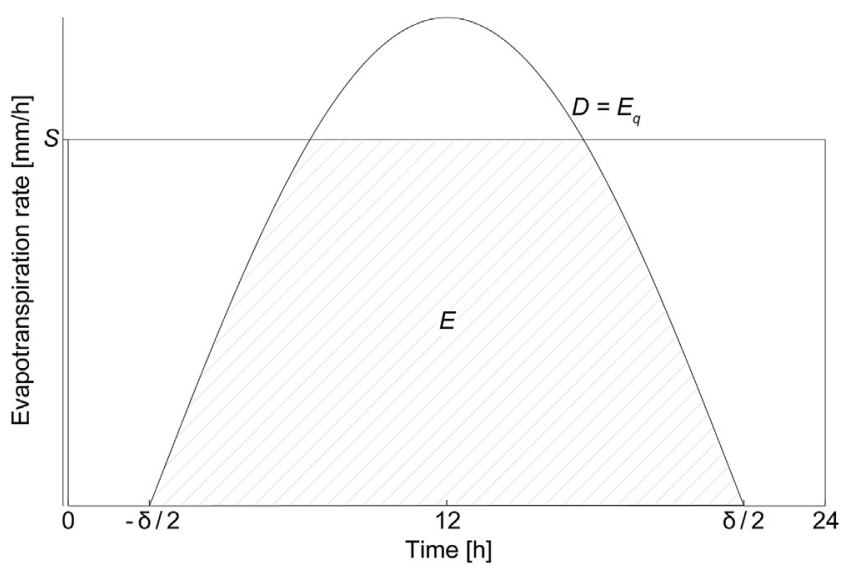

Fig. 1. The supply and demand scheme for calculating the daily evapotranspiration. The hatched area represents the actual evapotranspiration (Federer, 1982). 
a)

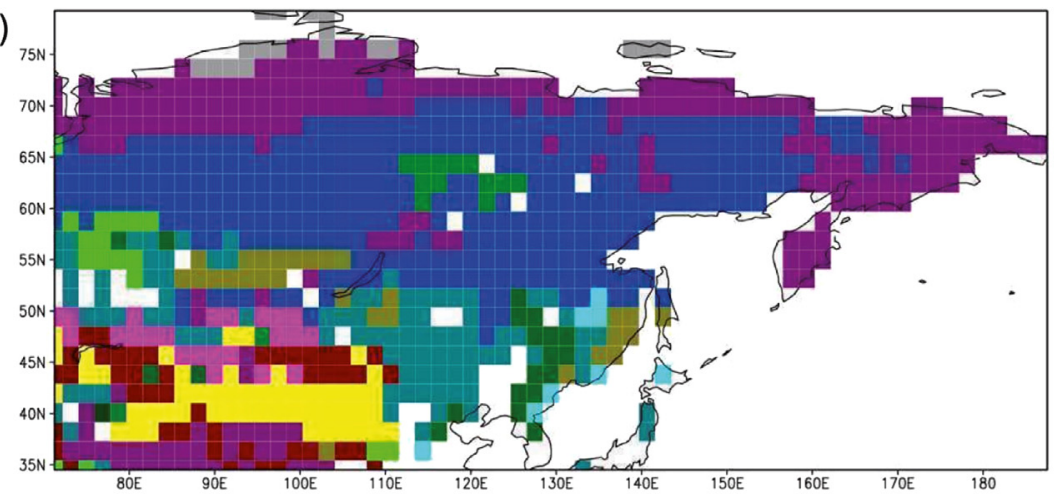

b)

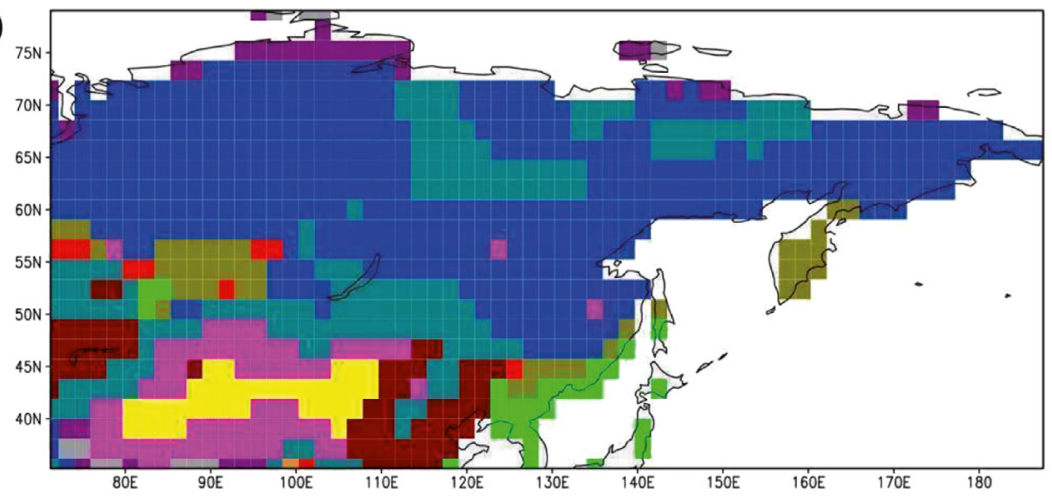

c)

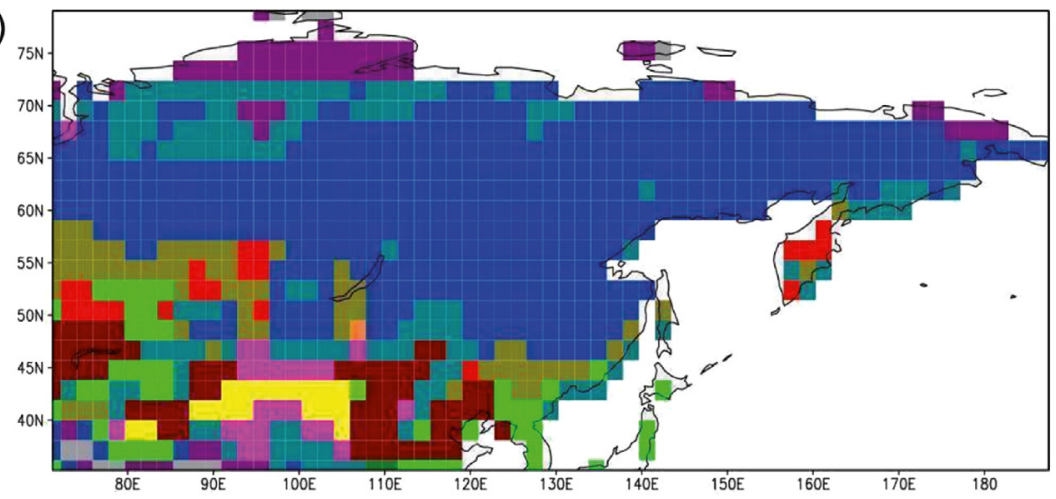

\section{Evergreen/Warm} mixed forest

Temperate deciduous forest

\section{Cool mixed} forest

\section{Cool conifer} forest
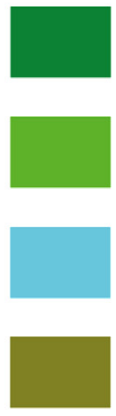

Taiga

\section{Cold mixed forest}

Warm grass/ shrub

Cool grass/ shrub

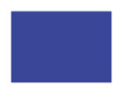

Tundra
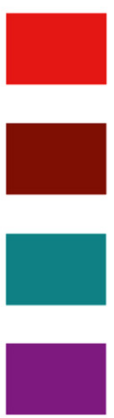

Hot

desert

\section{Semi} desert

\section{Ice/polar} desert

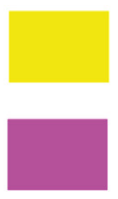

Not mapped

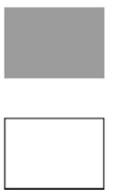

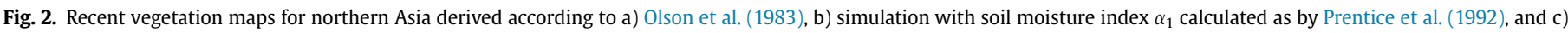
simulation with the soil moisture index $\alpha_{2}$ calculated by the alternatively implemented algorithm (this study).

If Equation (3) is integrated over a whole year the variability of the soil moisture content $\mathrm{d} m / \mathrm{d} t$ and the ground heat flux $G$ can be neglected. By introducing the Bowen-Ratio $\beta(\beta=H /[\lambda E])$ and substituting the sensible heat flux $H$ Equation (3) can be rewritten as following equation:

$\lambda E=R_{n}-H=\frac{R_{n}}{(1+\beta)}$

Equation (1) is still valid when the ground heat flux is neglected. Assuming that only mean values and no instantaneous or maximum values are considered one can calculate a proportion from (1) and (4). This leads to a term for the soil moisture index $\alpha_{2}$ and equation:

$\alpha_{2}=\frac{E}{E_{q}}=\frac{\Delta+\gamma}{\Delta(1+\beta)}$
Equation (5) is only valid as a value on a yearly basis. The advantages compared to the calculation of $\alpha_{1}$ are that there is no transient phase for the soil moisture and the calculation of $\alpha_{2}$ is universal. In the algorithm for the calculation of $\alpha_{1}$ the evapotranspiration rate is set to $c_{w}=1 \mathrm{~mm} / \mathrm{h}$, which is only valid for conditions under high water demand.

\section{Results}

\subsection{Test run with recent climate data}

In simulating the palaeovegetation, the implementation of the soil moisture index has to be tested first. Therefore, the vegetation model, including both algorithms, was driven with a recent climate dataset from the years 1979-2008 to calculate the modern vegetation distribution. However, a comparison of the simulated and observed maps of vegetation indicates several problems. First, 
there is no explicit convention for the definition of PFTs. Second, observational maps represent current vegetation and not natural potential vegetation simulated in the model. However, to compare the model results with observational data, we used the map compiled by Olson et al. (1983) as suggested by Prentice et al. (1992). This vegetation map $\left(0.5^{\circ} \times 0.5^{\circ}\right.$ grid resolution $)$ shows only the actual terrestrial vegetation and makes no built-in assumptions about the natural vegetation to be expected in a given area. Therefore, we excluded regions with strong human impact from the data-model comparison. Fig. 2 shows the model output for both parameterisation schemes in comparison to the modern vegetation map. In all three maps, the biome taiga is dominant. Furthermore, the cool conifer forest and warm grass/shrub biomes are in good agreement in all three vegetation maps. The main differences between modelled vegetation and the actual vegetation can be seen for cool grass/shrub and tundra. However, the biomes differ insignificantly. It should be noted that in the ecosystem classification of Olson et al. (1983) the biome cold deciduous forest is included in the biome taiga and is therefore not shown in the map comparison (Fig. 2). In general, the spatial biome distribution for both model simulations (i.e. using $\alpha_{1}$ and $\alpha_{2}$ ) is in relatively good agreement with the reference vegetation. The distribution of the most dominant biome, taiga, is in good agreement with the dataset from Olson et al. (1983). The spatial vegetation pattern for the eastern part of northern Asia correlates slightly better with the reference vegetation than for the western part. One exception can be seen for the Kamchatka peninsula, where, according to the reference vegetation, tundra is the main biome, whereas with both algorithms forest biomes are simulated. In particular, spatial differences between the simulations with $\alpha_{1}$ and $\alpha_{2}$ can be seen for the northern regions, where with $\alpha_{1}$ more forest ecosystems are simulated than with $\alpha_{2}$. For other parts of the study area, simulated vegetation patterns with the two moisture indices are in good agreement.

Examination of the results with weighted Cohens- $\kappa$-statistics allowed us to make quantitative statements about the quality of the two algorithms. This method is based on map comparison and calculates a measure for the 'inter-rater reliability' (Cohen, 1968), which means the level of agreement between different vegetation distribution estimates. It is generally thought to be a more robust measure than simple percent agreement calculation, as $\kappa$ takes into account the agreement occurring by chance. Every simulation with $\alpha_{1}$ and $\alpha_{2}$ is compared with the compiled modern vegetation map. The results are shown in Table 2. According to these, the biomes tundra and taiga show the highest variation of $\kappa$-values calculated with $\alpha_{1}$ and $\alpha_{2}$. Keeping in mind that these two biomes are most widespread in the considered region, the result underlines the importance of moisture index recalculation. Generally, the $\kappa$-values derived with the results obtained with $\alpha_{2}$ are in

Table 2

Weighted $\kappa$-values for the simulations that were driven by the NCEP reanalysis data. The modelled vegetation is compared with the data by Olson et al. (1983). $\alpha_{1}$ and $\alpha_{2}$ indicate the two algorithms for the calculation of the moisture index. $\Delta[\%]$ represents the percentage deviation of both $\kappa_{i}$-values.

\begin{tabular}{lllc}
\hline Biome-type & $\kappa_{i}\left(\alpha_{1}\right)$ & $\kappa_{i}\left(\alpha_{2}\right)$ & $\Delta[\%]$ \\
\hline Temperate deciduous forest & 0.21 & 0.18 & 17 \\
Cool conifer forest & 0.34 & 0.35 & 2.9 \\
Taiga & 0.24 & 0.49 & 51 \\
Warm grass/shrub & 0.14 & 0.33 & 58 \\
Cool grass/shrub & 0.24 & 0.18 & 33 \\
Tundra & 0.23 & 0.42 & 45 \\
Hot desert & 0.59 & 0.51 & 16 \\
Semidesert & 0.18 & 0.24 & 25 \\
Ice/polar desert & 0.44 & 0.55 & 20 \\
Total $(\kappa)$ & 0.28 & 0.37 & 24 \\
\hline
\end{tabular}

slightly better agreement with reconstruction results than those calculated with $\alpha_{1}$.

\subsection{Vegetation simulation for the $125 \mathrm{ka} \mathrm{BP}$ time-slice}

For the optimum of the LI cool/grass shrub and tundra are simulated only in the far north of the considered region (Fig. 3). A major part of the area north of $60^{\circ} \mathrm{N}$ was mainly covered with deciduous needle-leaved trees. In the south, taiga is mainly simulated with both algorithms $\alpha_{1}$ and $\alpha_{2}$. The ECHO-G climate output for the 125 ka BP time-slice shows significantly wetter conditions than today in northern Asia. The simulation with the moisture index $\alpha_{2}$ is resulting in forest biomes. It is notable that in contrast to $\alpha_{1}$, the simulation with $\alpha_{2}$ allowed us to simulate the tundra and cool grass/shrub biomes in the central Siberian plateau and the eastern Siberian mountains. The vegetation derived using the conventional algorithm for the soil moisture index does not differ from the Siberian lowland, for which cold deciduous forest is simulated. Significant differences between simulations with both algorithms appear for central Asia $\left(80^{\circ} \mathrm{E}-125^{\circ} \mathrm{E} / 37^{\circ} \mathrm{N}-47^{\circ} \mathrm{N}\right)$. In this region, biomes including cool and warm grass/shrub or tundra are more abundant with $\alpha_{1}$ calculation than with $\alpha_{2}$. On average, the northern tree-line simulated with $\alpha_{1}$ shifts about $3.3 \pm 1.9^{\circ}$, and with $\alpha_{2}$ about $4.8 \pm 2.1^{\circ}$ further north (Fig. 4). Fig. 5 shows the relative occurrence of simulated forest, shrub and desert biomes in the study region. Compared to the recent vegetation map of Olson et al. (1983), both algorithms for calculating the moisture index show increased tree cover for northern Asia. Mainly in the north of the study region the modern cool grass/shrub and tundra biomes are replaced by cold deciduous forest.

\subsection{Vegetation simulation for the $115 \mathrm{ka}$ BP time-slice}

The simulated vegetation for the end of the LI differs greatly compared to the optimum phase. At $115 \mathrm{ka} \mathrm{BP}$ the vegetation assemblage mainly shows a glacial character (Fig. 6). Especially, in the region north of $65^{\circ} \mathrm{N}$ the forest biomes are replaced by shrub biomes such as tundra or cool/grass shrub. The simulated climate change between the optimum and the end of the LI in the northern part has more impact on the vegetation composition than in the central part of northern Asia. Both simulations, with $\alpha_{1}$ and $\alpha_{2}$, are showing forest biomes between 55 and $47^{\circ} \mathrm{N}$. An exception is the Baikal Region, where, with the moisture index $\alpha_{2}$ tundra is simulated. The results with $\alpha_{1}$ show wetter conditions and the taiga biome. For central Asia, the climate model shows drier and colder conditions compared to the $125 \mathrm{ka}$ BP time-slice. The vegetation change in this region is particularly pronounced. In both simulations, the area covered with temperate forest is mainly represented by non-forest biomes including cool grass/ shrub, tundra and semidesert. In general, the climate simulation shows drier and cooler than present conditions, and thus forest biomes in northern Asia are replaced by grass and shrub formations. It is notable that with both simulations the Japanese Archipelago as well as the Kamchatka peninsula does not show significant vegetation change between the optimum and the end of the LI. For southern Sakhalin and northern Japan, simulation with both moisture indices show a replacement of taiga (simulated at $125 \mathrm{ka}$ BP) by cool conifer forest at $115 \mathrm{ka}$ BP. In general, vegetation changes with the $\alpha_{2}$ simulation are less pronounced compared to those calculated with $\alpha_{1}$ (Fig. 7). Due to the simulated significant changes in climate north of $65^{\circ} \mathrm{N}$, the tree-line shifts to southern regions at $115 \mathrm{ka} \mathrm{BP}$ (Fig. 8). With the $\alpha_{1}$ simulation the tree-line is shifted $9.8 \pm 4.3^{\circ}$ southwards, whereas with $\alpha_{2}$ the tree-line shifts $11 \pm 4^{\circ}$ to the south compared to 125 ka BP. 
a)

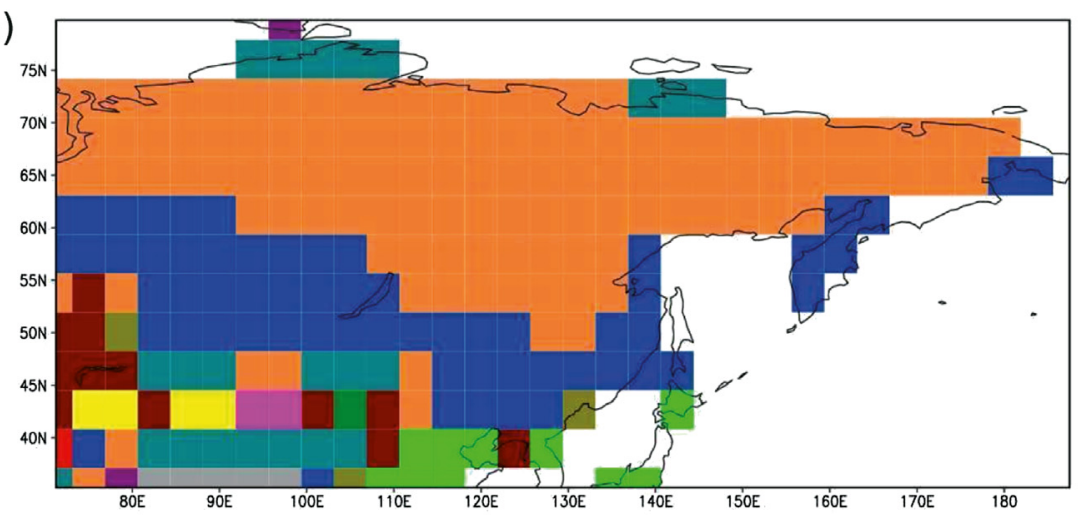

b)

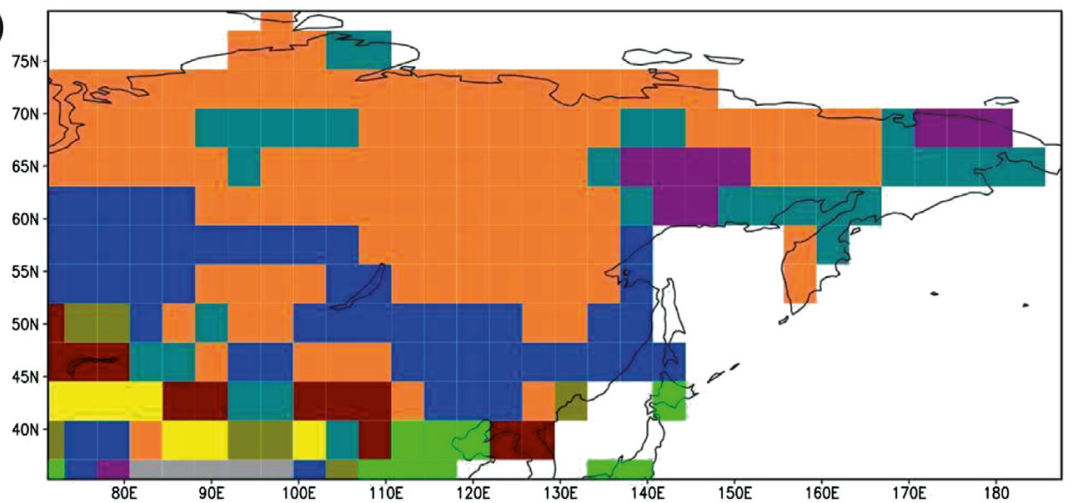

Temperate deciduous forest

\section{Cool conifer} forest

\section{Taiga}

\section{Cold deci-} duous forest

Warm grass/ shrub

\section{Cool grass/ shrub}

\section{Tundra}

Hot
desert
Semi
desert
Ice/polar
desert
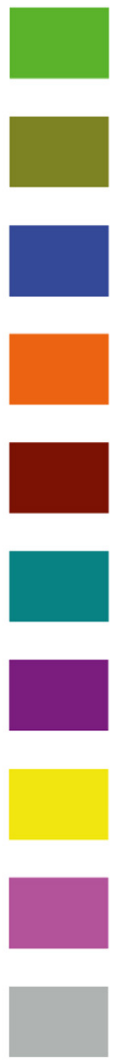

Fig. 3. Vegetation simulation for the 125 ka BP time-slice a) with the moisture index $\alpha_{1}$ (calculated as in Prentice et al, 1992) and b) with the moisture index $\alpha_{2}$ (this study).

\section{Discussion}

The main goal of this model experiment is the simulation of the vegetation for the optimum and the end phases of the $\mathrm{LI}$ (125 and 115 ka BP) using a new approach of calculating the moisture index (here $\alpha_{2}$ ) and comparison with results obtained using the conventionally calculated moisture index (here $\alpha_{1}$ ). To evaluate the model output, we compare the results with published pollen-based vegetation and climate reconstructions from northern Asia. There

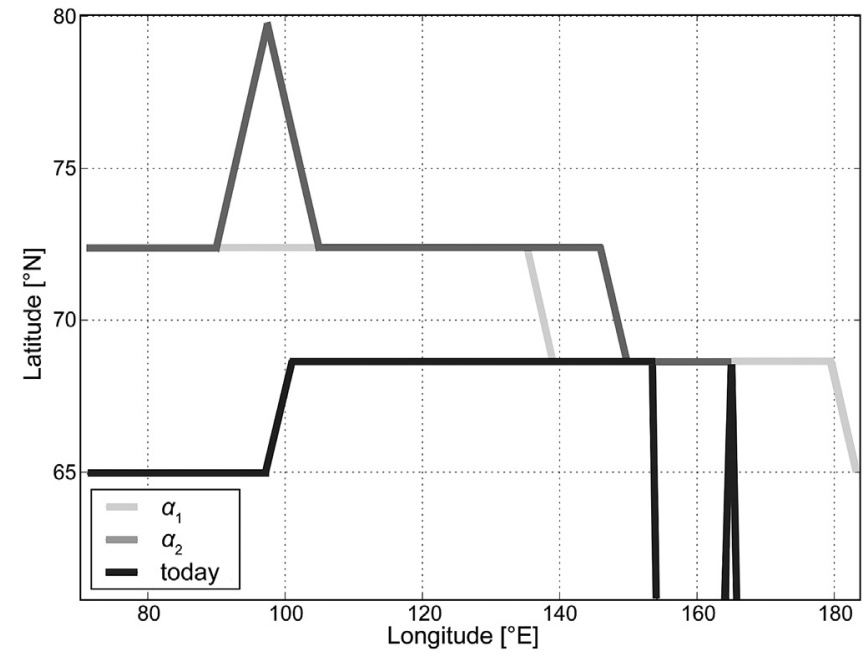

Fig. 4. Progression of the tree-line simulated with $\alpha_{1}$ and $\alpha_{2}$ for the 125 ka BP timeslice. For comparison the recent tree-line (Olson et al., 1983) is also shown. are some principal limitations of the proxy-derived vegetation and climate records that have to be considered within the study region. These are (i) regional differences in data availability; for example the relative scarcity of terrestrial records of the LI in Siberia compared to the numerous pollen stratigraphies of Europe and the western part of Russia, respectively (LIGA members, 1991); (ii) disparities between proxies in availability, utility and spatial and temporal resolution; and (iii) lack of absolute dating techniques of sufficient accuracy and resolution. Error bars for reconstructed

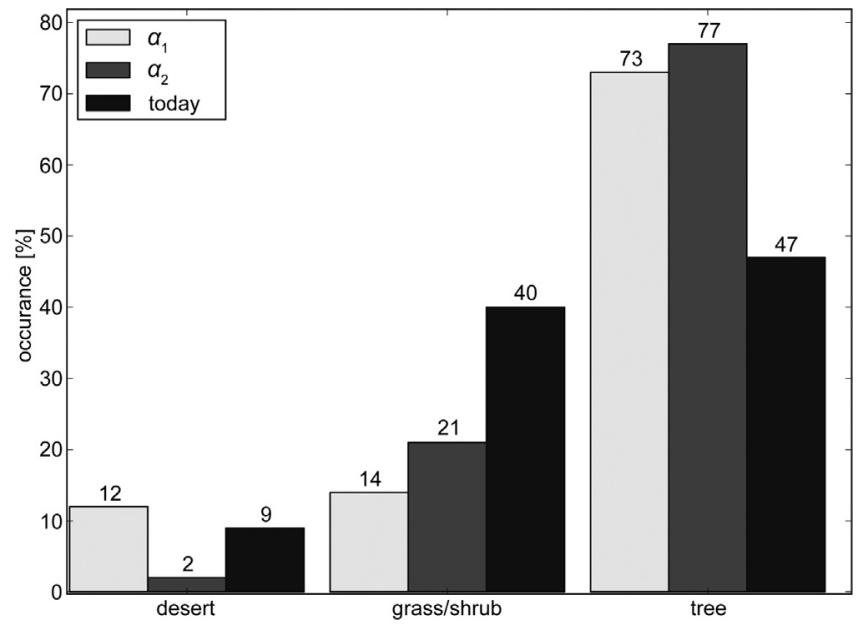

Fig. 5. Relative occurrence of desert-, grass-/shrub- and tree-like biomes for the $125 \mathrm{ka}$ BP time-slice simulation. For comparison the recent data (Olson et al., 1983) is also shown. 
climate parameters, if published at all, vary significantly between reconstruction methods and study sites.

The discussion of data-model comparison within this chapter is divided into three parts. First, we compare the simulated vegetation results with several pollen-based reconstructions. Then, the two calculated moisture indices are compared with the proxy reconstruction results. Finally, we compare the ECHO-G modelsimulated climate with several pollen-based reconstructions.

\subsection{Vegetation}

For the $125 \mathrm{ka} \mathrm{BP}$ time-slice, the most eligible dataset is presented in the "Atlas of paleoclimates and paleoenvironments of the Northern Hemisphere" by Frenzel et al. (1992). The map compiled for the vegetation during the LI was primarily composed using palaeobotanical data, including information from 119 sites in Siberia. To obtain quantitative estimates of palaeoclimates, they compared former vegetation communities and soil types to their nearest modern equivalents. The vegetation classification by Frenzel et al. (1992) differs from that applied in the model simulations, therefore reconstructed vegetation classes were assigned to the model biomes (Table 3). The reconstructions presented in Frenzel et al. (1992) are much more homogeneous than our model results. This is due to the interpolation of reconstruction results from a number of sites to a larger regular gridded area.

Table 3

Assignment of the biomes defined by Frenzel et al. (1992) to the ones defined by Prentice et al. (1992) that are utilized in the BIOME1 model.

\begin{tabular}{ll}
\hline Biome name according to Frenzel et al. (1992) & $\begin{array}{l}\text { Biome name in the } \\
\text { BIOME1 model }\end{array}$ \\
\hline $\begin{array}{l}\text { Herbs and shrubs, moss and shrub formations } \\
\text { of tundra types }\end{array}$ & Tundra \\
$\begin{array}{c}\text { Coniferous and coniferous-birch formations with } \\
\text { patches of tundra associations }\end{array}$ & Cold deciduous forest \\
$\begin{array}{l}\text { Coniferous formations with broad-leafed species } \\
\text { Species rich broad-leafed formations in plains } \\
\text { and mountain formations (broad-leafed } \\
\text { species with conifers) }\end{array}$ & $\begin{array}{l}\text { Taiga } \\
\text { Temperate deciduous } \\
\text { forest }\end{array}$ \\
$\begin{array}{l}\text { Species rich broad-leafed formations with } \\
\text { evergreen and conifer trees }\end{array}$ & Evergreen warm/mixed \\
$\begin{array}{l}\text { Subxerophilous bush-arboreal formations of broad- } \\
\text { leafed, deciduous and evergreen species with } \\
\text { conifers and formations of mountain xerophytes }\end{array}$ & Warm grass/shrub \\
$\begin{array}{l}\text { Subxerophilous and xerophilous herb-grass and } \\
\text { Artemisia-grass formations of steppe type }\end{array}$ & Xerophytic wood/scrub \\
$\begin{array}{l}\text { Xerophilous Artemisia-grass and bush formations } \\
\text { of desert type on low-lying plains and in low } \\
\text { mountains }\end{array}$ & Hot desert \\
$\begin{array}{l}\text { High mountain xerophilous vegetation and } \\
\text { desert type }\end{array}$ & Cool grass/shrub \\
\hline
\end{tabular}

The reconstruction and simulation results are mostly in good agreement for the northern and central part of the considered region. Only in the far north differences between the pollen-based reconstructions and the vegetation simulations with $\alpha_{2}$ should be mentioned. For most parts of the Siberian Arctic coast the model results simulated with $\alpha_{2}$ show the occurrence of cold deciduous forest, whereas the simulations with $\alpha_{1}$ and the reconstructions indicate tundra as the most dominant biome. Simulation results for the Siberian mountains differ from that of the lowlands and demonstrate that the simulations with $\alpha_{2}$ are in better agreement with the proxy-data for these regions. Major differences between vegetation simulations and reconstructions according to Frenzel et al. (1992), as e.g. the displacement of broad-leafed forests, only occur in the south and southwest of the considered region. In this area, mainly forest biomes are simulated with both moisture indices, whereas the vegetation reconstructions basically show grass and shrub formations as well as desert biomes.

We compared the LI simulation results with vegetation reconstructions from Lake Baikal sediments $\left(53.95^{\circ} \mathrm{N}, 108.9^{\circ} \mathrm{E}\right)$ published in Tarasov et al. (2005) and Granoszewski et al. (2005), permafrost profiles from Bol'shoy Lyakhovsky Island $\left(73.5^{\circ} \mathrm{N}\right.$, $142.5^{\circ} \mathrm{E}$ ) in Kienast et al. (2008), and a record from Lake Biwa $\left(35.28^{\circ} \mathrm{N}, 136.12^{\circ} \mathrm{E}\right.$ ) on Honshu (Tarasov et al., 2011). The differences are only related to the parameterisation of the moisture in$\operatorname{dex} \alpha$ (Table 4). Although both simulations indicate results that are different from the pollen-based reconstruction, the difference between cool grass/shrub and tundra can be seen as rather marginal (Table 4a). The difference between taiga, cool steppe, and tundra is very significant and can be explained by the increased moisture requirements of forest ecosystems. According to Prentice et al. (1992), forests demand a minimum moisture index of 0.65 . The data-model comparison results for the Bol'shoy Lyakhovsky Island (Table 4 b) indicate similar results to the comparison of simulations with the data from Frenzel et al. (1992). Kienast et al. (2008) reported a pronounced warming in northeastern Europe and northern Asia as the most distinctive feature of the LI optimum. Within the zone presently dominated by the Siberian anticyclone, January temperatures were higher by up to $6{ }^{\circ} \mathrm{C}$ compared to today (Frenzel et al., 1992). The data-model comparison for central Japan, Lake Biwa region (Table 4c), shows good correlation for 115 ka BP. Different results for $125 \mathrm{ka}$ BP can be explained by the temperature settings in the ECHO-G climate. The minimum $T_{C}$ values for the evergreen warm mixed forest biome have to be above $5{ }^{\circ} \mathrm{C}$. For the $125 \mathrm{ka}$ BP time-slice the $T_{c}$ values in the Japanese region are on average $0.074 \pm 0.47{ }^{\circ} \mathrm{C}$. The difference between the simulations and the proxy-data can rather be seen in the temperature than in the moisture conditions.

\section{Table 4}

Computed biomes in comparison with the proxy-data reconstruction from a) Lake Baikal (Tarasov et al., 2005), b) the Bol'shoy Lyakhovsky Island (Kienast et al., 2008) and c) Lake Biwa (Tarasov et al., 2011). EwF: evergreen warm mixed forest, TdF: temperate deciduous forest, Cs: cool steppe, Cdf: cold deciduous forest, Tu: tundra, Ta: taiga.

\begin{tabular}{|c|c|c|c|}
\hline \multirow[t]{2}{*}{ Regions and time-slices } & \multirow[t]{2}{*}{$\begin{array}{l}\text { Reconstructed } \\
\text { biomes }\end{array}$} & \multicolumn{2}{|c|}{$\begin{array}{l}\text { Modelled biomes } \\
\text { with moisture } \\
\text { index }\end{array}$} \\
\hline & & $\alpha_{1}$ & $\alpha_{2}$ \\
\hline \multicolumn{4}{|c|}{ a) Lake Baikal (Tarasov et al., 2005) } \\
\hline 125 ka BP & Ta & Ta & Тa \\
\hline 115 ka BP & Cs & Ta & $\mathrm{Tu}$ \\
\hline \multicolumn{4}{|c|}{ b) Bol'shoy Lyakhovsky Island (Kienast et al., 2008) } \\
\hline $125 \mathrm{ka} \mathrm{BP}$ & $\mathrm{Tu}$ & $\mathrm{Tu}$ & Cdf \\
\hline \multicolumn{4}{|c|}{ c) Lake Biwa (Tarasov et al., 2011) } \\
\hline $125 \mathrm{ka} \mathrm{BP}$ & EwF & TdF & TdF \\
\hline 115 ka BP & TdF & $\mathrm{TdF}$ & $\mathrm{TdF}$ \\
\hline
\end{tabular}

\subsection{Moisture index}

For comparison of the 125 ka BP time-slice, the vegetation and climate reconstructions provided by Tarasov et al. (2005) and Kienast et al. (2008) were used (Table 4). The pollen-based dataset provided by Tarasov et al. (2005) from Lake Baikal $\left(53.95^{\circ} \mathrm{N}\right.$, $\left.108.9^{\circ} \mathrm{E}\right)$ represents the central part of the study region. The reconstructions from Kienast et al. (2008) are based on pollen and plant macrofossil analyses from Bol'shoy Lyakhovsky Island, in the northern part of the study region. For an adequate data-model 
a)

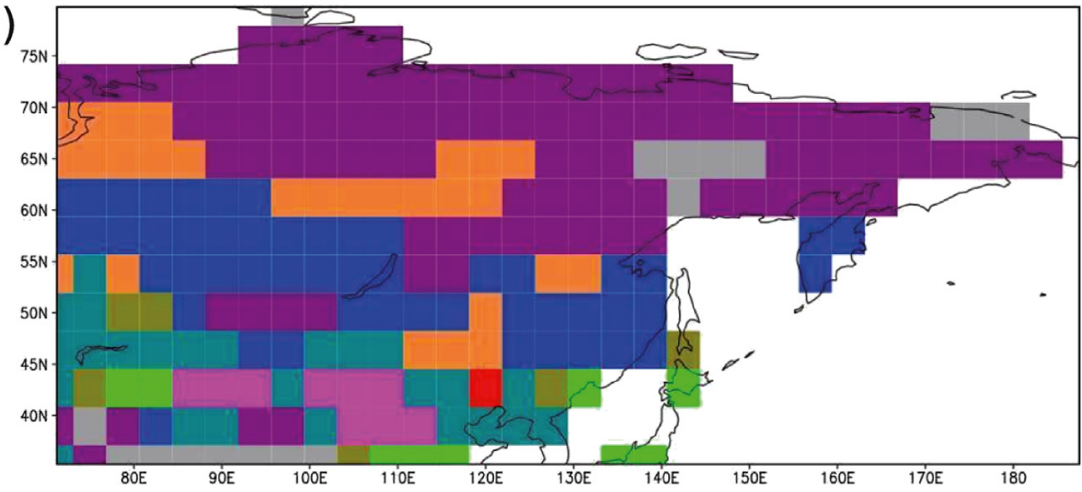

b)

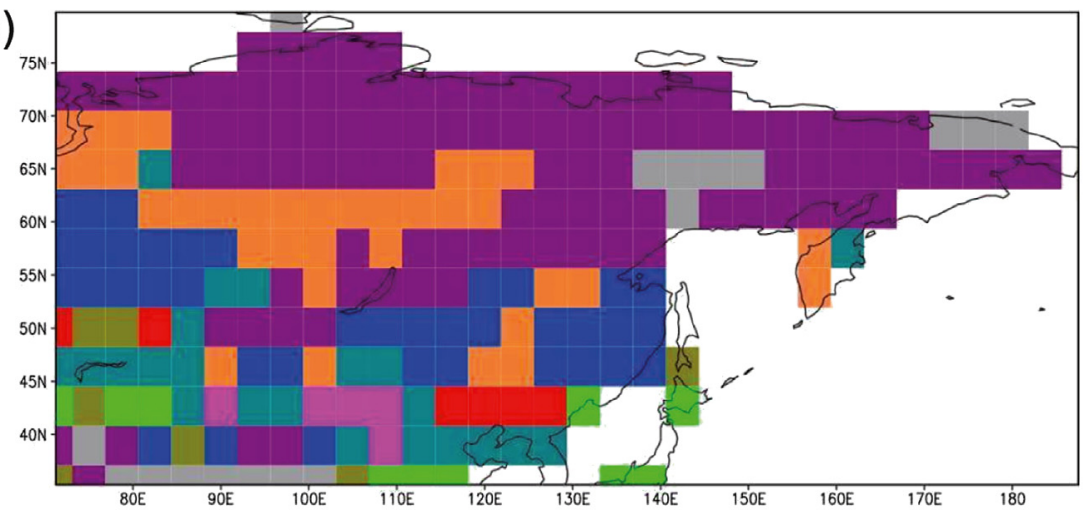

Temperate deciduous forest

Cool conifer forest

Taiga

\section{Cold deci- duous forest \\ Warm grass/ shrub}

Cool grass/ shrub
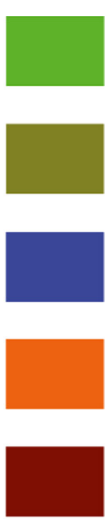

Tundra

\section{Hot} desert Semi
desert

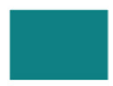
Ice/polar desert

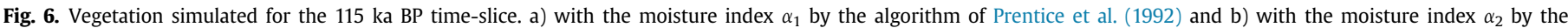
alternatively implemented algorithm.

comparison a weighted mean of the grid-box that corresponds to the pollen data origin is applied (as shown in Fig. 9). Fig. 10 shows the data-model comparison using both simulated moisture indexes and the pollen-based reconstruction (Tarasov et al., 2005) for the 125 ka BP time-slice at Lake Baikal. For the Lake Baikal region (Fig. 10), 19\% of the values for $\alpha_{1}$ lie outside the error range of the proxy-data. The mean difference between $\alpha_{1}$ and $\alpha_{2}$ is with $4.4 \times 10^{-2} \pm 4.9 \times 10^{-2}$ considerable small (Table 5). Taking the error ranges of the proxy-data and twofold standard deviations of the model simulations into account both simulations are in good agreement with the pollen-based reconstructions. The simulated values for $\alpha_{1}$ and $\alpha_{2}$ for the Bol'shoy Lyakhovsky Island are significantly underestimated.

\section{Table 5}

Comparison of the calculated moisture indices with the one reconstructed by Tarasov et al. (2005) from Lake Baikal and Bol'shoy Lyakhovsky Island (Kienast et al., 2008).

\begin{tabular}{|c|c|c|c|}
\hline \multirow{2}{*}{$\begin{array}{l}\text { Regions and time-slices } \\
\text { a) Lake Baikal (Tarasov e }\end{array}$} & \multirow{2}{*}{$\begin{array}{l}\text { Reconstruction } \\
\text { results for } \alpha\end{array}$} & \multicolumn{2}{|c|}{$\begin{array}{l}\text { Modelled results for } \alpha_{1} \\
\text { and } \alpha_{2}\end{array}$} \\
\hline & & & \\
\hline $125 \mathrm{ka}$ & $0.96+0.05 /-0.15$ & $0.93 \pm 0.05$ & $0.97 \pm 0.02$ \\
\hline $115 \mathrm{ka}$ & $0.49+0.00 /-0.07$ & $0.94 \pm 0.03$ & $0.63 \pm 0.04$ \\
\hline \multicolumn{4}{|c|}{ b) Bol'shoy Lyakhovsky Island (Kienast et al., 2008) } \\
\hline $125 \mathrm{ka}$ & $0.99+0.00 /-0.00$ & $0.78 \pm 0.03$ & $0.80 \pm 0.03$ \\
\hline
\end{tabular}

For data-model comparison at $115 \mathrm{ka} \mathrm{BP}$, only reconstructions from Lake Baikal are available. The results of the data-model comparison for this time-slice are significantly different, compared to the reconstruction for the $125 \mathrm{ka}$ BP time-slice. The pollen-based data show a mean deviation of $0.46 \pm 0.03$ for $\alpha_{1}$ and $0.14 \pm 0.04$ for $\alpha_{2}$. The mean deviation between the results of both algorithms is $0.31 \pm 0.05$. The value for the moisture index $\alpha_{1}$ is rather similar to the one for the $125 \mathrm{ka}$ BP time-slice. With help of the $\alpha_{1}$-calculation forest biomes are simulated, whereas the model results with $\alpha_{2}$ as well as the reconstruction results show nonforest biomes (Table 4). Although $\alpha_{2}$ for the $115 \mathrm{ka}$ time-slice is decreased by $0.34 \pm 0.04$ compared to the $125 \mathrm{ka}$, the values are completely out of the error range of the pollen-based reconstruction. The relatively large difference between the simulated values of $\alpha_{1}$ and the reconstruction can be influenced by the different precipitation amounts. Further model experiments where all input

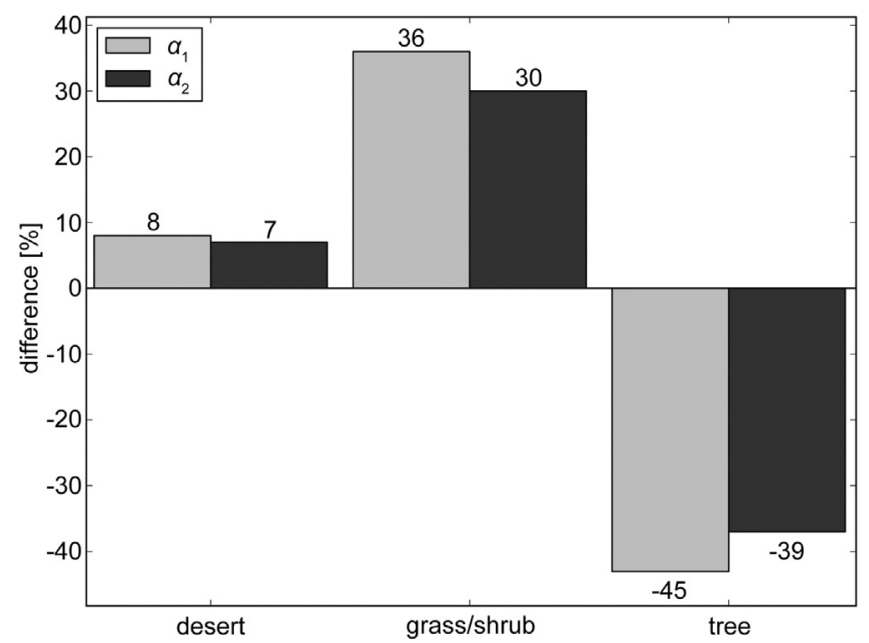

Fig. 7. Variability of tree-, grass/shrub and desert biomes between the simulations for the 125 and $115 \mathrm{ka}$ BP time-slice in the considered region, $\alpha_{1}$ and $\alpha_{2}$ indicates the algorithm for the calculation of the moisture index. 
variables are varied by $\pm 25 \%$ respective $\pm 50 \%$ show that the moisture index $\alpha_{1}$ is eminently sensitive to precipitation. The precipitation within the ECHO-G model climate on the other hand is on average $400 \pm 20 \mathrm{~mm}$, and thus approximately $48.9 \pm 8.0 \%$ higher than the proxy-data reconstructions, which are on average $280+20 /-30 \mathrm{~mm}$ (Tarasov et al., 2005).

\subsection{Data-model comparison for the ECHO-G climate data}

The proxy-data as well as the biome simulation show a tree-line that is shifted northwards compared to recent conditions. In the model simulations the occurrence of tree vegetation north of $70^{\circ} \mathrm{N}$ can be explained by ECHO-G simulated warmer winter temperatures despite decreased solar radiation. These results correspond to the climate reconstructions reported in Velichko et al. (2008). The to one of the main challenges of climate simulation, which is to solve problems of precipitation prognosis (IPCC, 2007). The results of the data-model comparison in the present work confirm that the parameterisation of precipitation is still a source of uncertainty. The presented alternative method of calculating moisture requirements (index $\alpha$ ) in order to simulate the vegetation still contains problematic variables. Although the precipitation is not directly taken into account for the computation of $\alpha_{2}$, the latent heat flux is still difficult to parameterise. On the one hand, latent heat is related to humidity processes, and on the other hand this variable is turbulent and thus has to be parameterised in a climate model (Roeckner et al., 1992, 1996, 2003). The latter results in a number of difficulties, as described by Baklanov et al. (2011). Nevertheless, the alternatively implemented algorithm $\left(\alpha_{2}\right)$ for the calculation of the moisture index $\alpha$ has two main advantages:

Table 6

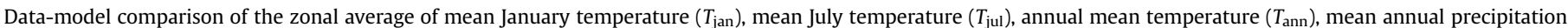

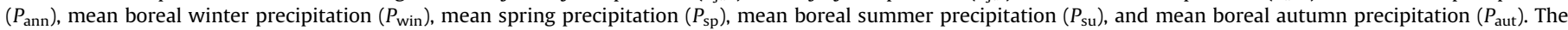
standard deviations are calculated by the single values of the grid-points respective of the data points within each zone. The proxy-data are from Velichko et al. (2008).

\begin{tabular}{|c|c|c|c|c|c|c|c|c|}
\hline & $T_{\text {jan }}\left({ }^{\circ} \mathrm{C}\right)$ & $T_{\mathrm{jul}}\left({ }^{\circ} \mathrm{C}\right)$ & $T_{\text {ann }}\left({ }^{\circ} \mathrm{C}\right)$ & $P_{\mathrm{ann}}(\mathrm{mm})$ & $P_{\text {win }}(\mathrm{mm})$ & $P_{\mathrm{sp}}(\mathrm{mm})$ & $P_{\mathrm{su}}(\mathrm{mm})$ & $P_{\text {aut }}(\mathrm{mm})$ \\
\hline \multicolumn{9}{|l|}{$61^{\circ} \mathrm{N}-80^{\circ} \mathrm{N}$} \\
\hline Proxy-data & $-22 \pm 3$ & $15 \pm 2$ & $-4 \pm 3$ & $420 \pm 105$ & $61 \pm 24$ & $69 \pm 26$ & $165 \pm 36$ & $119 \pm 35$ \\
\hline $\begin{array}{l}\text { ECHO-G } \\
50^{\circ} N-61^{\circ} N\end{array}$ & $-34 \pm 8$ & $5 \pm 12$ & $-14 \pm 4$ & $313 \pm 146$ & $40 \pm 33$ & $51 \pm 30$ & $114 \pm 53$ & $106 \pm 47$ \\
\hline Proxy-data & $-19 \pm 4$ & $18 \pm 2$ & $0 \pm 1$ & $550 \pm 150$ & $63 \pm 4$ & $113 \pm 18$ & $293 \pm 46$ & $158 \pm 39$ \\
\hline $\begin{array}{l}\text { ECHO-G } \\
38^{\circ} N-50^{\circ} N\end{array}$ & $-18 \pm 14$ & $10 \pm 10$ & $-5 \pm 6$ & $652 \pm 189$ & $120 \pm 97$ & $124 \pm 30$ & $193 \pm 40$ & $210 \pm 91$ \\
\hline Proxy-data & $-12 \pm 6$ & $19 \pm 2$ & $4 \pm 3$ & $595 \pm 293$ & $82 \pm 78$ & $122 \pm 69$ & $255 \pm 148$ & $155 \pm 78$ \\
\hline ECHO-G & $-9 \pm 13$ & $15 \pm 8$ & $3 \pm 4$ & $733 \pm 392$ & $178 \pm 75$ & $189 \pm 76$ & $189 \pm 76$ & $205 \pm 140$ \\
\hline
\end{tabular}

comparison of their reconstructions and the ECHO-G model output is shown in Table 6. As both algorithms tend to compute increased moisture conditions in the south of the considered region, a possible explanation can be the overestimation of precipitation and latent heat flux in the ECHO-G climate model. This assumption is also justified by the precipitation reconstructions of Velichko et al. (2008), where for the south of the considered region higher precipitation values are simulated than the reconstructions show. The differences between the reconstructions and the simulations can also be seen in the significant differences between the vegetation reconstruction by Frenzel et al. (1992) and the biome simulations that are driven with the ECHO-G climate model output. This leads

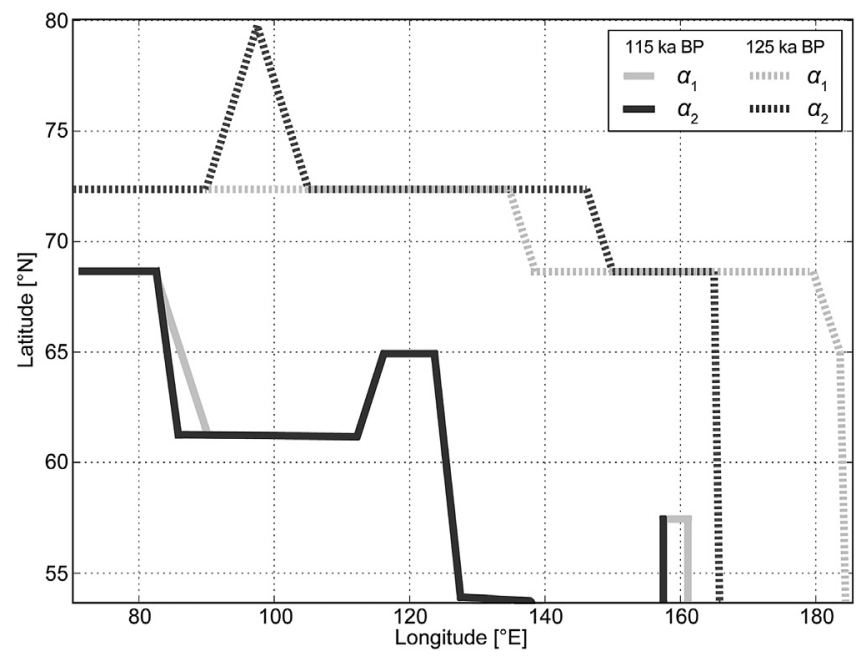

Fig. 8. Tree-line shift between the optimum (125 ka BP) and the end (115 ka BP) of the LI calculated with help of the moisture indices $\alpha_{1}$ and $\alpha_{2}$. (i) the available water capacity is not taken into account. This has two benefits: first of all, the transient phase on the first simulation year is omitted. Secondly, the field capacity itself is a problematic variable as there is a feedback between vegetation cover and available water capacity. The soil moisture content at field capacity is treated as constant in the model and thus this feedback is not taken into account.;

(ii) for calculation of $\alpha_{1}$, the transpiration rate in the soil moisture model is assumed to be $1 \mathrm{~mm} / \mathrm{h}$, independent from the vegetation cover. In areas with a transpiration rate higher than $1 \mathrm{~mm} / \mathrm{h}$ the soil water model will accumulate soil water, leading to an increased moisture budget. If the average transpiration rate is less than $1 \mathrm{~mm} / \mathrm{h}$, the moisture budget will be underestimated.

\section{Conclusions}

The objective of this study is to simulate vegetation dynamics at the optimum and the end of the LI in northern Asia with the help of the BIOME1 model. The simulation is based on two time-slice simulations with the ECHO-G climate model (i.e. 125 and $115 \mathrm{ka}$ $\mathrm{BP}$, respectively). For the purpose of simulating the vegetation, an alternatively implemented algorithm to calculate a plant's moisture budget is tested. To validate the adapted BIOME1 model, it is driven with recent climate data, and the results are compared with a modern vegetation map. For the map comparison, a weighted Fleiss- $\kappa$-statistics is used with satisfactory results. Furthermore, the alternatively implemented algorithm for calculating the moisture index $\alpha_{2}$ shows a slightly better agreement with the recent reference vegetation. The simulation results with the help of the ECHO$\mathrm{G}$ climate data show changing conditions between the 125 and the 115 ka BP time slices, from warmer conditions and typical interglacial vegetation to a vegetation with glacial characteristics. Thus, 


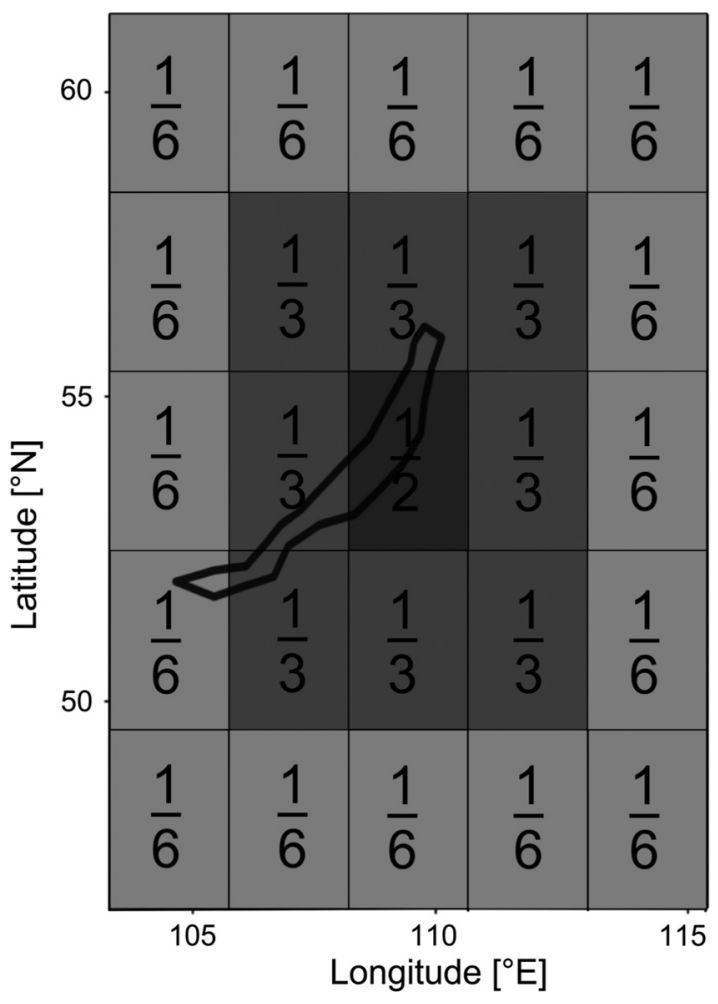

Fig. 9. Weight scheme applied to the data-model comparison. The grid-box indicates the proxy-data-origin that corresponds to the model grid. The numbers represent each grid cell applied weight.

for the optimum of the LI, the taiga and cold deciduous forest biomes are simulated as most dominant. Compared to recent conditions, the tree-line is located further north. The tree-covered area for the $125 \mathrm{ka}$ BP time-slice is approximately increased by $25 \%$. According to the simulations for the end of the LI, the tundra biome is most dominant in the study area.

The comparison of model simulations with palaeovegetation reconstructions based on proxy records from different sites within northern Asia helps to evaluate the results objectively and to

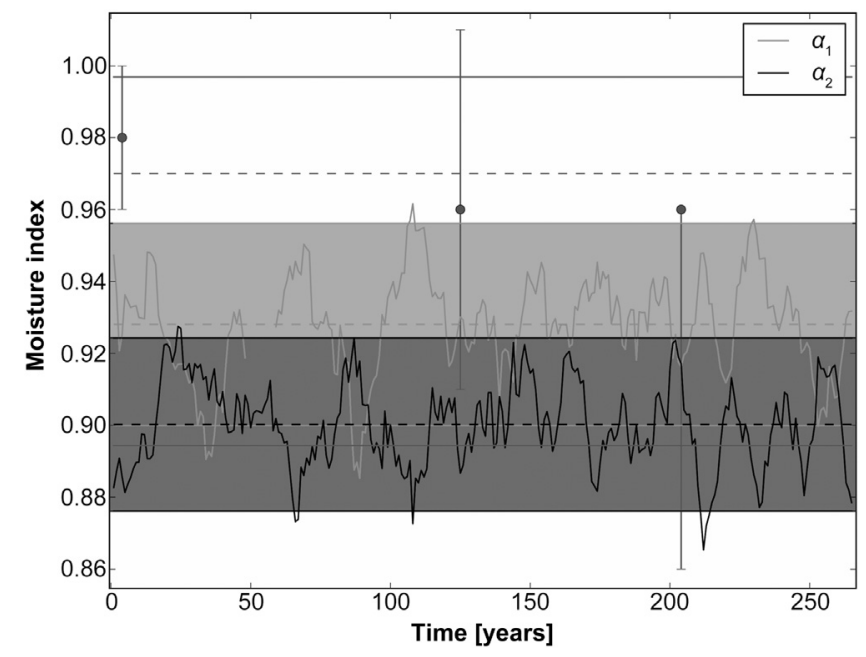

Fig. 10. Comparison of the calculated moisture indices with the $125 \mathrm{ka}$ BP values reconstructed by Tarasov et al. (2005) indicated by black dots (including error bars); light and dark grey bars indicate the twofold standard deviation range for each simulated dataset, respectively. improve our understanding of the role of different climate variables on past environments. For the LI optimum (125 ka BP), model simulation and reconstruction results are generally in agreement. For the end of LI (115 ka BP), the moisture indices $\alpha_{1}$ and $\alpha_{2}$ differ considerably.

A data-model comparison for the Lake Baikal region indicates an improvement of the vegetation simulations with the moisture index $\alpha_{2}$. For this region, the simulation with $\alpha_{1}$ computes forest biomes, whereas the reconstruction and the simulation with the help of $\alpha_{2}$ suggest non-forest biomes. Despite its intermediate level of complexity, the BIOME1 model is capable of simulating the vegetation satisfactorily. Nevertheless, an adequate estimation of a plant's moisture budget remains problematic. A possible improvement, as described in this study, comes with an alternative algorithm for calculating the moisture index $\alpha$. Further improvements can be reached with an advanced parameterisation scheme of the evapotranspiration itself. Thus, future work should be dedicated to the application of the adapted BIOME1 model in dynamically downscaled climate simulations for the study region of northern Asia.

\section{Acknowledgements}

We would like to thank Deutsche Forschungsgemeinschaft for financing the work of S. Müller (DFG 3181/1). Dr. F. Kaspar and Prof. $\mathrm{U}$. Cubasch are acknowledged for providing the climate simulation data of their ECHO-G simulations. We also greatly acknowledge Prof. P. Tarasov for his useful suggestions. J. Evers (FU Berlin) is thanked for editing the graphics and A. Beck for proofreading. Furthermore, we would like to acknowledge the constructive comments of two anonymous reviewers to a former version of this manuscript. All ECHO-G simulation results can be found at the CERA database of DKRZ (German climate computation centre).

\section{References}

Ajami, H., Meixner, T., Maddock, T., Hogan, J.F., Guertin, D.P., 2011. Impact of landsurface elevation and riparian evapotranspiration seasonality on groundwater budget in modflow models. Hydrogeology Journal 19 (6), 1181-1188.

Baklanov, A.A., Grisogono, B., Bornstein, R., Mahrt, L., Zilitinkevich, S.S., Taylor, P., Larsen, S.E., Rotach, M.W., Fernando, H.J.S., 2011. The nature, theory, and modeling of atmospheric planetary boundary layers. Bulletin of the American Meteorological Society 92 (2), 123-128.

Berger, A., 1978. Long-term variations of daily insolation and Quaternary climate changes. Journal of Atmospheric Science 35, 2362-2367.

Brewer, S., Guiot, J., Sánchez-Goñi, M.F., Klotz, S., 2008. The climate in Europe during the Eemian: a multi-method approach using pollen data. Quaternary Science Reviews 27, 2303-2315.

Cohen, J., 1968. Weighted kappa: nominal scale agreement provision for scaled disagreement or partial credit. Psychological Bulletin 70 (4), 213-220.

Crucifix, M., Loutre, M.F., 2002. Transient simulations over the last interglacial period (126-115 kyr BP): feedback and forcing analysis. Climate Dynamics 19, $417-433$.

Cubasch, U., Zorita, E., Kaspar, F., Gonzalez-Rouco, J.F., von Storch, H., Prömmel, K. 2006. Simulation of the role of solar and orbital forcing on climate. Advances in Space Research 37 (8), 1629-1634.

Cuffey, K.M., Marshall, S.J., 2000. Substantial contribution to sea-level rise during the last interglacial from the Greenland ice sheet. Nature 404, 591-594.

Federer, C.A., 1982. Transpirational supply and demand: plant, soil, and atmospheric effects evaluated by simulation. Water Resources Research 2 (2), 355-362.

Foley, J.A., Kutzbach, J.E., Coe, M.T., 1994. Feedbacks between climate and boreal forests during the Holocene epoch. Nature 371, 52-54.

Frenzel, B., Pécsi, M., Velichko, A.A., 1992. Atlas of Paleoclimates and Paleoenvironments of the Northern Hemisphere. Gustav Fischer Verlag.

Gallée, H., van Ypersele, J., Fichefet, T., Tricot, C., Berger, A., 1991. Simulation of the last glacial cycle by a coupled, sectorially averaged climate-ice sheet model part I: the climate model. Geographical Review 96 (13), 139-161.

Granoszewski, W., Demske, D., Nita, M., Heumann, G., Andreev, A.A., 2005. Vegetation and climate variability during the Last Interglacial evidenced in the pollen record from Lake Baikal. Global and Planetary Change 46, 187-198.

Harrison, S.P., Kutzbach, J.E., Prentice, I.C., Behling, P.J., Sykes, M.T., 1995. The response of Northern Hemisphere extratropical climate and vegetation to orbitally induced changes in insolation during the Last Interglaciation. Quaternary Research 43, 174-184. 
Hibler, W.D., 1979. A dynamic thermodynamic sea ice model. Journal of Physical Oceanography 9, 817-846.

IPCC, 2007. Climate Change 2007: the Physical Science Basis. In: Fourth Assessment Report of the Intergovernmental Panel on Climate Change. Cambridge University Press, Cambridge, United Kingdom and New York, USA.

Jouzel, J., Masson-Delmotte, V., Dreyfus, G., Falourd, S., Hoffmann, G., Minster, B., Nouet, J., Barnola, J.M., Chappellaz, J., Fischer, H., Gallet, J.C., Johnsen, S., Leuenberger, M., Luethi, D., Oerter, H., Parrenin, F., Raisbeck, G., Raynaud, D. Schilt, A., Schwander, J., Selmo, E., Souchez, R., Spahni, R., Stauffer, B. Steffensen, J.P., Stenni, B., Stocker, T.F., Tison, J.L., Werner, M., Wolff, E.W., 2007. Orbital and millennial Antarctic climate variability over the past 800,000 years. Science 317, 793-796.

Kageyama, M., Peyron, O., Pinot, S., Tarasov, P., Guiot, J., Joussaume, S., Ramstein, G. 2001. The last glacial maximum climate over Europe and western Siberia: a PMIP comparison between models and data. Climate Dynamics 17, 23-43.

Kalnay, E., Kanamitus, M., Kistler, R., Collins, W., Deaven, D., Gandin, L., Iredell, M., Saha, S., White, G., Woollen, J., Zhu, Y., Chelliah, M., Ebisuzaki, W., Higgins, W. Janowiak, J., Mo, K.C., Ropelwski, C., Wang, J., Leetmaa, A., Reynolds, R., Jenne, R., Joseph, D., 1996. The NCEP/NCAR 40-year Reanalysis Project. Project Description. NCEP/NCAR, Boulder.

Kaplan, J., Bigelow, N., Prentice, I., Harisson, S., Bartlein, P., Christensen, T., Cramer, W., Matveyeva, N., McGuire, A., Murray, D., Razzhivin, V., Smith, B., Walker, D., Anderson, P., Andreev, A., Brubaker, L., Edwards, M., Lozhkin, A 2003. Climate change and Arctic ecosystems: 2. Modelling, paleodatamodel comparisons, and future projections. Journal of Geophysical Research 108, 8171. http://dx.doi.org/10.1029/2002JD002559.

Kaspar, F., Kühl, N., Cubasch, U., Litt, T., 2005. A model-data comparison of European temperatures in the Eemian interglacial. Geophysical Research Letters 32, L11703. http://dx.doi.org/10.1029/2005GL022456.

Kaspar, F., Spangehl, T., Cubasch, U., 2007. Northern hemisphere winter storm tracks of the Eemian interglacial and the last glacial inception. Climate of the Past 3 , $181-192$.

Kienast, F., Tarasov, P.E., Schirrmeister, L., Grosse, G., Andreev, A.A., 2008. Continental climate in the east Siberian Arctic during the last interglacial: implications from palaeobotanical records. Global and Planetary Change 60 (3-4), $535-562$.

Kleinen, T., Tarasov, P., Brovkin, V., Andreev, A., Stebich, M., 2011. Comparison of modeled and reconstructed changes in forest cover through the past 8000 years: Eurasian perspective. Holocene 21, 723-734.

Krinner, G., Viovy, N., de Noblet-Ducoudré, N., Ogée, J., Polcher, J., Friedlingstein, P., Ciais, P., Sitch, S., Prentice, I.C., 2005. A dynamic global vegetation model for studies of the coupled atmosphere-biosphere system. Global Biogeochemical Cycles 19, GB1015. http://dx.doi.org/10.1029/2003GB002199.

Kubatzki, C. Montoya, M., Rahmstorf, S., Ganopolski, A., Claussen, M., 2000. Comparison of the last interglacial climate simulated by a coupled global model of intermediate complexity and an AOGCM. Climate Dynamics 16, 799-814.

Kukla, G.J., Bender, M.L., de Beaulieu, J.-L., Bond, G.S.W., Cleveringa, B.P., Gavin, J.E. Herbert, T.D., Imbrie, J., Jouzel, J., Keigwin, L.D., Knudsen, K.-L., McManus, J.F., Merkt, J., Muhs, D.R., Müller, H., Poore, R.Z., Porter, S.C., Seret, G. Shackleton, N.J., Turner, C., Tzedakis, P.C., Winograd, I.J., 2002. Last interglacial climates. Quaternary Research 58, 2-13.

Legutke, S., Maier-Reimer, E., 1999. Climatology of the HOPE-G Global Ocean-Sea Ice General Circulation Mode (Technical Report 21). Deutsches Klimarechenzentrum, Hamburg, Germany.

Legutke, S., Voss, R., 1999. The Hamburg Atmosphere-Ocean Coupled Model ECHOG (Technical Report 18). German Climate Computer Center (DKRZ).

Lettau, H., 1969. A new approach to numerical prediction of monthly evapotranspiration, runoff and soil moisture storage. Monthly Weather Review 97 (10), 691-699.

LIGA members, Anderson, P., Borisova, O., de Beaulieu, J.-L., de Vernal, A. Eiriksson, J., Funder, S., Gibbart, P., Hamilton, T., Harrison, S.P., HoumarkNielsen, M., Huntley, B., Knudsen, K.L., Larsen, E., Maher, L.J., Matthews, J.V., Miller, G., Raukas, A., Reeh, N., Robertsson, A.-M., Rutter, N., Schweger, C.E., Sejrup, H.-P., Sher, A., Telka, A., Turner, C., Velichko, A., Ward, B., 1991. Report of 2nd discussion group: Inter-Relationships and linkages between the land, atmosphere and oceans during the last interglacial. Quaternary International, 10-12, 29-48.

Melles, M., Brigham-Grette, J., Minyuk, P.S., Nowaczyk, N.R., Wennrich, V., DeConto, R.M. Anderson, P.M. Andreev, A. A Coletti, A, Cook, T.L, HaltiaHovi, E., Kukkonen, M., Lozhkin, A.V., Rosén, P., Tarasov, P., Vogel, H., Wagner, B. 2012. 2.8 Million years of Arctic climate change from lake El'gygytgyn, NE Science 337, 315-320.

Min, S.-K., Legutke, S., Hense, A., Kwon, W.-T., 2005a. Internal variability in a $1000-$ yr control simulation with the coupled climate model ECHO-G - part I: nearsurface temperature, precipitation and mean sea level pressure. Tellus A 57 (4), 605-621.

Min, S.-K., Legutke, S., Hense, A., Kwon, W.-T., 2005b. Internal variability in a 1000yr control simulation with the coupled climate model ECHO-G - part II. Enso and Nao. Tellus A 57 (4), 622-640.

Monserud, R.A., Leemans, R., 1992. Comparing global vegetation maps with the kappa statistic. Ecological Modelling 62, 275-293.
Monteith, J.L., 1965. Evaporation and environment. Symposia of the Society for Experimental Biology 19 (1), 205-224.

NOAA, NCAR, 1949-2011. The NCEP/NCAR Reanalysis Project (cdas). GPL.

Olson, J.S., Watts, J.A., Allison, L.J., 1983. Major World Ecosystem Complexes Ranked by Carbon in Live Vegetation: a Database. Oak Ridge National Laboratory.

Petit, J.R., Jouzel, J., Raynaud, D., Barkov, N.I., Barnola, J.-M., Basile, I., Bender, M., Chappellaz, J., Davis, M., Delaygue, G., Delmotte, M., Kotlyakov, V.M., Legrand, M., Lipenkov, V.Y., Lorius, C., Pepin, L., Ritz, C., Saltzman, E., Stievenard, M., 1999. Climate and atmospheric history of the past 420,000 years from the Vostok ice core, Antarctica. Nature 399, 429-436.

Prentice, I.C., Sykes, M.T., Cramer, W., 1991. A simulation model for the transient effects of climate change on forest landscapes. Ecological Modelling 65, 51-70.

Prentice, I.C., Cramer, W., Harrison, S.P., Leemans, R., Monserud, R.A., Solomon, A.M. 1992. A global biome model based on plant physiology and dominance, soil properties and climate. Journal of Biogeography 17, 117-134.

Prentice, I.C., Guiot, J., Huntley, B., Jolly, D., Cheddadi, R., 1996. Reconstructing biomes from palaeoecological data: a general method and its application to European pollen data at 0 and $6 \mathrm{ka}$. Climate Dynamics 12 (3), 185-194.

Prentice, I.C., Bondeau, A., Cramer, W., Harrison, S.P., Hickler, T., Lucht, W., Sitch, S. Smith, B., Sykes, M.T., 2007. Dynamic global vegetation modelling: quantifying terrestrial ecosystem response to large-scale environmental change. In: Canadell, J.G., Pataki, D.E., Pitelka, L.F. (Eds.), Terrestrial Ecosystems in a Changing World. Springer, pp. 175-192.

Priestley, C., Taylor, R.J., 1972. On the assessment of surface heat flux and evaporation using large-scale parameters. Monthly Weather Review 100 (2), 81-92.

Roeckner, E., Arpe, K., Bengtsson, L., Brinkop, S., Dümenil, L., Esch, M., Kirk, E., Lunkeit, F., Ponater, M., Rockel, B., Sausen, R., Schlese, U., Schubert, S., Windelband, M., 1992. Simulation of the Present-day Climate with the ECHAM Model: Impact of Model Physics and Resolution (Report 93). Max Planck Institute for Meteorology, Hamburg, Germany.

Roeckner, E., Arpe, K., Bengtsson, L., Christoph, M., Claussen, M., Dümenil, L.M., Esch, M.G., Schlese, U., Schulzweida, U., 1996. The Atmospheric General Circulation Model ECHAM4: Model Description and Simulation of Present-day Climate (Report 218). Max Planck Institute for Meteorology, Hamburg, Germany.

Roeckner, E., Bäuml, G., Bonaventura, L., Brokopf, R., Esch, M., Giorgetta, M., Hagemann, S., Kirchner, I., Kornblueh, L. Manzini, E., Rhodin, A., Schlese, U. Tompkins, S.A., 2003. The Atmospheric General Circulation Model ECHAM-5 Part I (Report 349). Max Planck Institute for Meteorology, Hamburg, Germany.

Sánchez Goñi, M.F., Loutre, M., Crucifix, M., Peyron, O., Santos, L., Duprat, J., Malaizé, B., Turon, J.-L., Peypouquet, J.-P., 2005. Increasing vegetation and climate gradient in western Europe over the last glacial inception (122-110 ka): data-model comparison. Earth and Planetary Science Letters 231 (1-2), 111130.

Schurgers, G., Mikolajewicz, U., Gröger, M., Maier-Reimer, E., Vizcaíno, M., Winguth, A., 2006. Dynamics of the terrestrial biosphere, climate and atmospheric $\mathrm{CO}_{2}$ concentration during interglacials: a comparison between Eemian and Holocene. Climate of the Past 2, 205-220.

Sitch, S., Smith, B., Prentice, I., Arneth, A., Bondeau, A., Cramer, W., Kaplan, J., Levis, S., Lucht, W., Sykes, M., Thonicke, K., Venevsky, S., 2003. Evaluation of ecosystem dynamics, plant geography and terrestrial carbon cycling in the LPJ dynamic global vegetation model. Global Change Biology 9, 161-185.

Sowers, T., 2001. $\mathrm{N}_{2} \mathrm{O}$ record spanning the penultimate deglaciation from the Vostok ice core. Journal of Geophysical Research 31, 903-914.

Tarasov, P., Granoszewski, W., Bezrukova, E., Brewer, S., Nita, M., Abzaeva, A., Oberhänsli, H., 2005. Quantitative reconstruction of the last interglacial vegetation and climate based on the pollen record from Lake Baikal, Russia. Climate Dynamics 25, 625-637.

Tarasov, P.E., Nakagawa, T., Demske, D., Österle, H., Igarashi, Y., Kitagawa, J., Mokhova, L., Bazarova, V., Okuda, M., Gotanda, K., Miyoshi, N., Fujiki, T., Takemurak, K., Yonenobu, H., Fleck, A., 2011. Progress in the reconstruction of Quaternary climate dynamics in the northwest Pacific: a new modern analogue reference dataset and its application to the 430-kyr pollen record from Lake Biwa. Earth-Science Reviews 108, 64-79.

Texier, D., de Noblet, N., Harrison, S.P., Haxeltine, A. Jolly, D, Joussaume, S, Laarif, F, Prentice, I.C. Tarasov, P., 1997. Quantifying the role of biosphere-atmosphere feedbacks in climate change: coupled model simulations for 6000 years BP and comparison with palaeodata for northern Eurasia and northern Africa. Climate Dynamics 13, 865-882.

Velichko, A.A., Borisova, O.K., Zeilikson, E.M., 2008. Paradoxes of the last interglacial climate: reconstruction of the northern Eurasian climate based on palaeofloristic data. Boreas 37, 1-19.

Wilson, K.B., Hanson, P.J., Mulholland, P.J., Baldocchi, D.D., Wullschleger, S.D., 2001. A comparison of methods for determining forest evapotranspiration and its components: sap-flow, soil water budget, eddy covariance and catchment water balance. Agricultural and Forest Meteorology 106 (2), 153168.

Wolff, J., Maier-Reimer, E., Legutke, S., 1997. The Hamburg Primitive Equation Model HOPE (Technical Report 18). German Climate Computer Center (DKRZ).

Woodward, F.I., Cramer, W., 1996. Plant functional types and climatic change: introduction. Journal of Vegetation Science 7 (3), 306-308. 